\title{
Secretory organelles of pathogenic protozoa
}

\author{
WANDERLEY DE SOUZA* \\ Laboratório de Ultraestrutura Celular Hertha Meyer, Instituto de Biofísica Carlos Chagas Filho \\ CCS-Bloco G, Universidade Federal do Rio de Janeiro, Ilha do Fundão \\ 21949-900 Rio de Janeiro, RJ, Brasil \\ Manuscript received on September 6, 2005; accepted for publication on February 1, 2006.
}

\begin{abstract}
Secretory processes play an important role on the biology and life cycles of parasitic protozoa. This review focus on basic aspects, from a cell biology perspective, of the secretion of (a) micronemes, rhoptries and dense granules in members of the Apicomplexa group, where these organelles are involved in the process of protozoan penetration into the host cell, survival within the parasitophorous vacuole and subsequent egress from the host cell, (b) the Maurer's cleft in Plasmodium, a structure involved in the secretion of proteins synthesized by the intravacuolar parasite and transported through vesicles to the erythrocyte surface, (c) the secretion of macromolecules into the flagellar pocket of trypanosomatids, and (d) the secretion of proteins which make the cyst wall of Giardia and Entamoeba, with the formation of encystation vesicles.
\end{abstract}

Key words: parasitic protozoa, cell secretion, Apicomplexa, trypanosomatids, encystation vesicles.

\section{INTRODUCTION}

The protozoa kingdom comprises a large number of species, including some which are agents of human and veterinary diseases such as malaria, leishmaniasis, Chagas' disease, African trypanosomiasis, amebiasis, trichomoniasis, giardiasis, toxoplasmosis, coccidiosis, theileriosis, and babesiosis, to mention only those more important. Some of these protozoa, as is the case of Trichomonas, present a simple life cycle. For others, however, as occurs with Apicomplexa (which includes Plasmodium, Toxoplasma, Eimeria, etc), and some trypanosomatids, the life cycle is relatively complex, displaying several developmental stages in the vertebrate host and, in some cases, in invertebrate hosts. These protozoa are also of interest from the cell biology point of view since they present spe-

*Member Academia Brasileira de Ciências

E-mail: wsouza@biof.ufrj.br cial cytoplasmic structures and organelles, which have been studied in some detail in the last years providing new information of general biological interest. In a previous review we analyzed organelles involved in the metabolic pathways (De Souza 2002). Here, we intend to review, from a cell biology perspective, organelles involved in secretory processes. We will not emphasize aspects well covered in a previous review (Becker and Melkonian 1996).

\section{CELL SECRETION IN APICOMPLEXA}

Since the first studies on the fine structure of protozoa belonging to the Apicomplexa group, especially studies carried out with $T$. gondii, Eimeria and Plasmodium, it became clear that the anterior region of the infective forms (trophozoites, merozoites, sporozoites) was highly specialized, forming what is generally known as the apical complex 
(Fig. 1). In addition to cytoskeleton components, such as the conoid-sub-pellicular microtubules complex, two organelles were initially recognized and designated as micronemes and rhoptries. Later on another structure, which can be found in other regions of the protozoan body, was recognized and designated as dense granules.

Apicomplexan protozoa present a typical endoplasmic reticulum with associated ribosomes. In T. gondii the ER is distributed throughout the cell and the nuclear envelope itself provides a significant fraction of the ER. Vesicles with a fuzzy coat bud off from the nuclear envelope and the ER. In Plasmodium the ER is less well developed. Several cisternae of the Golgi complex are observed in the anterior region, just above the nucleus of $T$. gondii. Vesicles with a clathrin-like coat bud off from the trans portion of the Golgi complex. Proteins such as COP I and II, Arf 1 and Sar 1, involved in vesicle formation at the ER-Golgi complex system, have been found in T. gondii (Review in Joiner and Roos 2002, Ngô et al. 2000).

\section{The Micronemes}

Micronemes are small, cigar-shaped organelles that are restricted to the apical third of the protozoan body. Their number varies according to the species and the developmental stages. In some species are hardly seen while in others are so numerous that correspond to the most abundant organelle found in the cell (Fig. 2). The organelle is surrounded by a typical unit membrane and presents an electron dense matrix due to its large protein content. Indeed the organelle is intensely stained when the protozoa are submitted to the ethanolic phosphotungstic acid technique, which reveals basic proteins (De Souza and Souto-Padrón 1978). At present, we still do not have a clear explanation for this labeling pattern since the known micronemal proteins have isolectric points lower than 7.0. All proteins found in the micronemes are synthesized with an $\mathrm{N}$-terminal signal sequence that mediates their entrance into the secretory pathway by translocation across the endoplasmic reticulum membrane. A mutagenesis anal- ysis of the C-terminal portion of MIC2 showed the presence of two conserved amino acid motifs mediating the target of this protein to the micronemes (Di Cristina et al. 2000). One motif is a tyrosinebased signal and the other one consists of a stretch of acidic residues.

Many of the micronemal proteins are glycosylated as seen by labeling of the micronemes when thin sections of $T$. gondii are incubated in the presence of gold-labeled lectins (Carvalho et al. 1991).

It has been shown that when the infective forms of Apicomplexan parasites touch the host cell surface they trigger a process of $\mathrm{Ca}^{2+}$ release and the discharge of the content of the micronemes at the junction between the parasite and the host cell (Carruthers et al. 1999a, Bouchot et al. 1999, Vieira and Moreno 2000) which then mediates parasite attachment (Carruthers et al. 1999a, b, Carruthers and Sibley 1999). This process takes place in a few seconds and the released proteins are not incorporated together with the parasites but instead are capped and released from the posterior end of the protozoan (Carruthers et al. 1999a). During redistribution on the parasite surface, transmembrane MICs are thought to connect external receptors to the submembranous acto-myosin motor that provides the power for parasite motility. Chelating of parasite intracellular $\mathrm{Ca}^{2+}$ inhibited both microneme release and invasion of host cells. What is the origin of the $\mathrm{Ca}^{2+}$ used by the protozoan? There is enough data indicating that the $\mathrm{Ca}^{2+}$ used for protozoan motility, micronemal secretion and cell invasion comes from organelles found in the protozoan. Fluorescence microscopy of protozoa labeled with the calcium indicator fluo-4 showed that cytosolic calcium levels underwent dramatic and rapid fluxes (Lovett and Sibley 2003). Several protozoan organelles, such as the endoplasmic reticulum, the Golgi complex, the mitochondrion and the acidocalcisomes may store calcium (Moreno and Zhong 1996, Review in Arrizabalaga and Boothroyd 2004). It has been shown that there is an intracellular calcium release channel with properties of the inositol 1,4,5-triphosphate/ryanodine receptor su- 


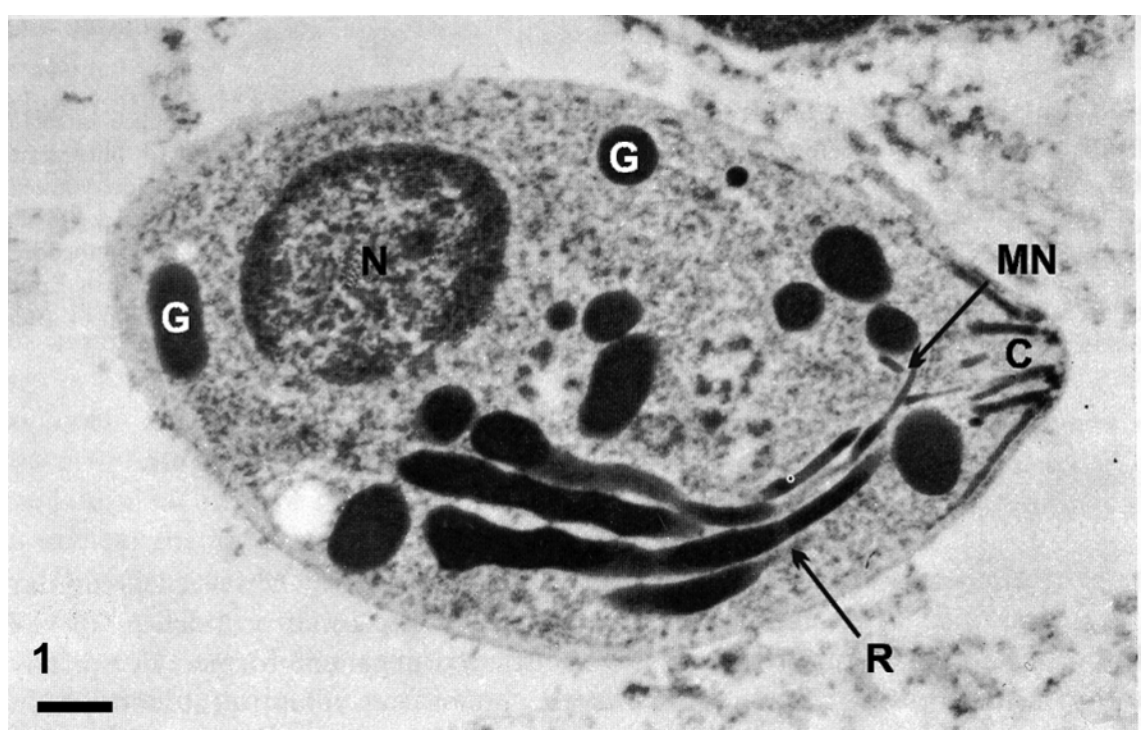

Fig. 1 - Transmission electron microscopy of a tachyzoites of Toxoplasma gondii submitted to the ethanolic phosphotungstic acid technique, which labels structures containing basic proteins. In addition to the nucleus $(\mathrm{N})$, staining of the dense granules $(\mathrm{G})$, Rhoptries (R), Micronemes $(\mathrm{M})$ and the Conoid (C) is observed. Bar, $0.3 \mu \mathrm{m}$. After De Souza and Souto-Padrón 1978.

perfamily (Lovett et al. 2002).

It has been shown that isoforms of phosphoglucomutase, a cytosolic enzyme, are implicated in $\mathrm{Ca}^{2+}$-mediated signaling events. One isoform, known as parafusin, plays an important role during exocytic activity in ciliated protozoa (Zhao and Satir 1998). A protein called parafusin-related protein has been identified in T. gondii and showed to be localized to an apical subpopulation of miconemes and to be redistributed during invasion of the host cell by the protozoan (Matthiesen et al. 2001a, b).

Several micronemal proteins contain one or more adhesive motifs found in mammalian proteins such as Epidermal Growth Factor, integrins, thrombospondin and kallikrein. Four of them, all designated as MIC (MIC1-4, from micronemal proteins), have been studied in some detail.

MIC1 has a size of $60 \mathrm{kDa}$ and contains two degenerate repeats similar to an adhesive sequence found in thrombospodin and known as type I repeats (TSP-I), and is able to bind to the host cell surface (Fourmaux et al. 1996). It has been shown that it is a lactose-binding lectin (Lourenço et al. 2001). It was also shown that its $\mathrm{N}$-terminal portion functions as an independent adhesin and promotes association with TgMIC4. A galectin-like domain interacts and stabilizes TgMIC6 (Saouros et al. 2005). Single deletion of MIC1 gene decreased invasion of fibroblasts and slightly reduced virulence of the parasite to mouse (Cérède et al. 2005).

MIC2 has a size of $115 \mathrm{kDa}$ and comprises an adhesive $\mathrm{N}$-terminal integrin-like A domain that has been implicated in binding ICAM 1 (Barragan et al. 2005) and glycosaminoglycans (Harper et al. 2004), which are ubiquitous sulfated proteoglycans found in the extracellular matrix. MIC2 also displays six thrombospodin type-1 repeats that also have the potential to bind glycosaminoglycans (Wan et al. 1997). It has been shown that a second micronemal protein, known as M2AP, facilitates the transport of MIC2 through the secretory pathway (Huynh et al. 2003, Rabenau et al. 2001). These two proteins seem to form stable hexamers consist- 


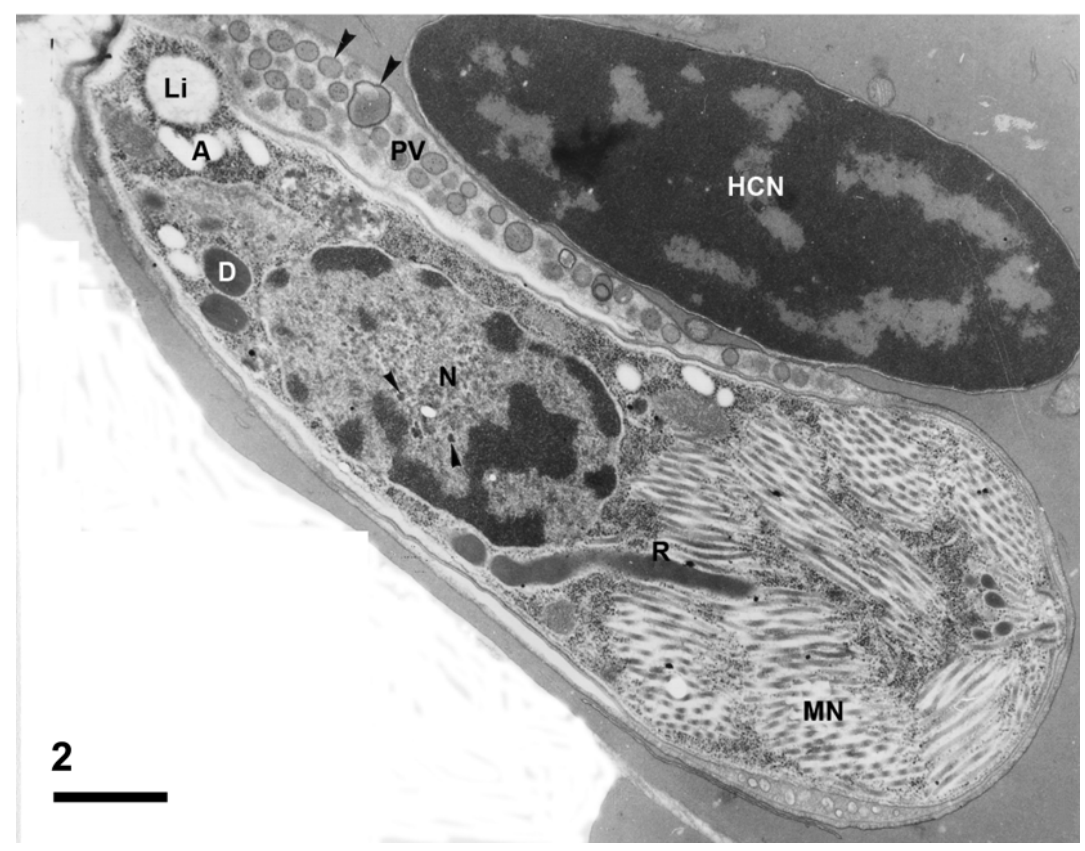

Fig. 2 - Routine transmission electron microscopy showing a trophozoite of Cyrilia lignieresi, a haemogregarine found in erythrocytes of a fresh-water fish. Structures such as lipidic inclusions (Li), amilopectin granules (A), dense granules (D), rhoptries (R) and a large number of micronemes $(\mathrm{M})$ are observed. Spherical bodies are seen within the flagellar pocket (small arrowheads). HCN, host cell nucleus. Bar, $1 \mu \mathrm{m}$. After Diniz et al. 2002.

ing of three $\alpha \beta$ dimmers (Jewett and Sibley 2004).

Following discharge MIC2 is proteolitically cleaved by proteases with release of its ectodomain from the parasite surface, a process that seems to be involved on parasite invasion (Carruthers et al. 2000, Brossier et al. 2003). Recently, proteins belonging to the rhomboid family of intramembranecleaving serine proteases, designated as TgROMs, were detected (Brossier et al. 2005, Dowse et al. 2005).

The binding of MIC2 to the host cell surface may establish connection between the host cell surface receptor and the cytoskeleton machinery of the parasites activating the gliding process necessary for the penetration of the parasite into the host cell. It has been shown that Plasmodium sporozoites, which do not express a homologue of MIC2, known as TRAP, fail to glide or invade host cells (Sultan et al. 1997).
MIC3 has a size of $90 \mathrm{kDa}$ and possesses five partially overlapping epidermal growth factor (EGF) domains and an $\mathrm{NH}_{2}$ terminal chitin bindinglike domain, which probably are also involved in the process of parasite association to the host cell surface (Fourmaux et al. 1996, Soldati et al. 2001). It is a disulfide-linked heterodimer comprised of two $38 \mathrm{kDa}$ isoforms (Achbarou et al. 1991). Single substitution of two critical amino acids in the chitin binding-like domains of this protein abolished its binding to cells and decrease parasite virulence (Cérède et al. 2005).

MIC 4 contains six domains and it binds to host cells (Brecht et al. 2001). In the case of Eimeria tenella $\mathrm{MIC} 4$ is a transmembrane protein with a molecular weight of $240 \mathrm{kDa}$, containing 31 tandemly arranged EGF-like repeats in the extracellular domain. These repeats have calcium binding consensus that seem to be involved in make the 
molecule to adopt a protease-resistant, rigid structure that could favor its interaction with host cell ligands (Periz et al. 2005).

MIC 6, which is a transmembrane protein, forms trimeric complexes with soluble micronemal proteins such as MIC1 and MIC 4, functioning as an escort protein. Deletion of MIC 6 prevents targeting of these two proteins to the microneme (Reiss et al. 2001). MIC 8 also seems to work as a escort protein to MIC 3 (Meissner et al. 2002).

In Plasmodium falciparum a micronemal protein, known as EBA 175, has been shown to bind to sialic acid (Sim 1995) a molecule, which plays a fundamental role on the process of parasite-erythrocyte interaction.

More recently several other proteins which do not present recognizable adhesive motifs have been identified in the micronemes of $T$. gondii. TgMIC 5 has homology to the parvulin family of peptidyl prolyl cis-trans isomerases and may assist in the folding of other micronemal proteins (Brydges et al. 2000). Other proteins, including Tg MIC10 entirely devoid of cysteines, were recently identified (Hoff et al. 2001). MIC 11, a $16 \mathrm{kDa}$ protein, was recently identified in several coccidian parasites. During its traffic through the secretory pathway it is proteoliticaly cleaved with removal of an internal propeptide, resulting in a mature form containing a $\alpha$-chain and a $\beta$-chain tethered by a single disulfide bond (Harper et al. 2004).

Members of the genus Plasmodium present several developmental stages, which are able to invade different cells in both vertebrate and invertebrate cells. For instance, merozoites invade vertebrate red blood cells, the ookinete invades epithelial cells of the insect vector while sporozoites invade the salivary gland epithelial cells of the insect and when inoculated into the vertebrate host, traverse several cellular barriers until invade hepatic cells. Recent studies have shown that Plasmodium presents several genes coding for proteins, which present a membrane-attack complex/perforin-like domain. One of these proteins (PLP1/SPECT2) found in sporozoites was shown to be localized in the micronemes (Kaiser et al. 2004) and is necessary for cell traversal (Ishino et al. 2005). Genes encoding proteins with similar properties were identified in the genome of Eimeria and Toxoplasma.

\section{THE RHOPTRIES}

Rhoptries are long, club-shaped organelles connected by thin necks to the extreme apical pole of the parasite (Figs. 1-4). At their basal portion the matrix of the organelle shows a spongeous appearance while the neck region is uniformly electron dense making it difficult the distinction from the micronemes. Their number varies according to the species. Several can be seen in $T$. gondii whereas only two, often designated as paired organelle, are found in Plasmodium. The organelle is surrounded by a typical unit membrane and is heavily stained with ethanolic phosphotungstic acid (Fig. 1) (De Souza and Souto-Padrón 1978). Cytochemical studies have shown the presence of glycconjugates and lectin-like molecules (Carvalho et al. 1991) and $\mathrm{Ca}^{2+}$ (Pezzela et al. 1997) in the rhoptries. All proteins found in the rhoptries were synthesized in the endoplasmic reticulum and passed through the Golgi complex. Members of the ROP2 family contain multiple independent targeting signals (Bradley and Boothroyd 2001, Striepen et al. 2001). ROP 2 displays both YXX $\Phi$ and LL motifs. Deletion or alteration of these motifs abolishes protein delivery to the rhoptries, with its accumulation in a post Golgi compartment (Review in Joiner and Roos 2002). There is some evidence that rhoptry proteins after leaving the Golgi complex are first accumulated in an intermediate compartment, a type of immature rhoptry which is a acidic organelle, with a $\mathrm{pH}$ of 3.5 to 5.5 whereas the mature organelle has a pH of 5.0 to 7.0 as determined using the DAMP technique (Metsis et al. 1995, Shaw et al. 1998). Based on this fact and the involvement of both secretory and endocytic pathways in the rhoptry formation it has been considered that this organelle is equivalent to a lysosome (Metsis et al. 1995, Ngô et al. 2004). More recently, a novel $\mathrm{Na}^{+} / \mathrm{H}^{+}$exchanger, designated as $\mathrm{TgNEH} 2$, was localized in 


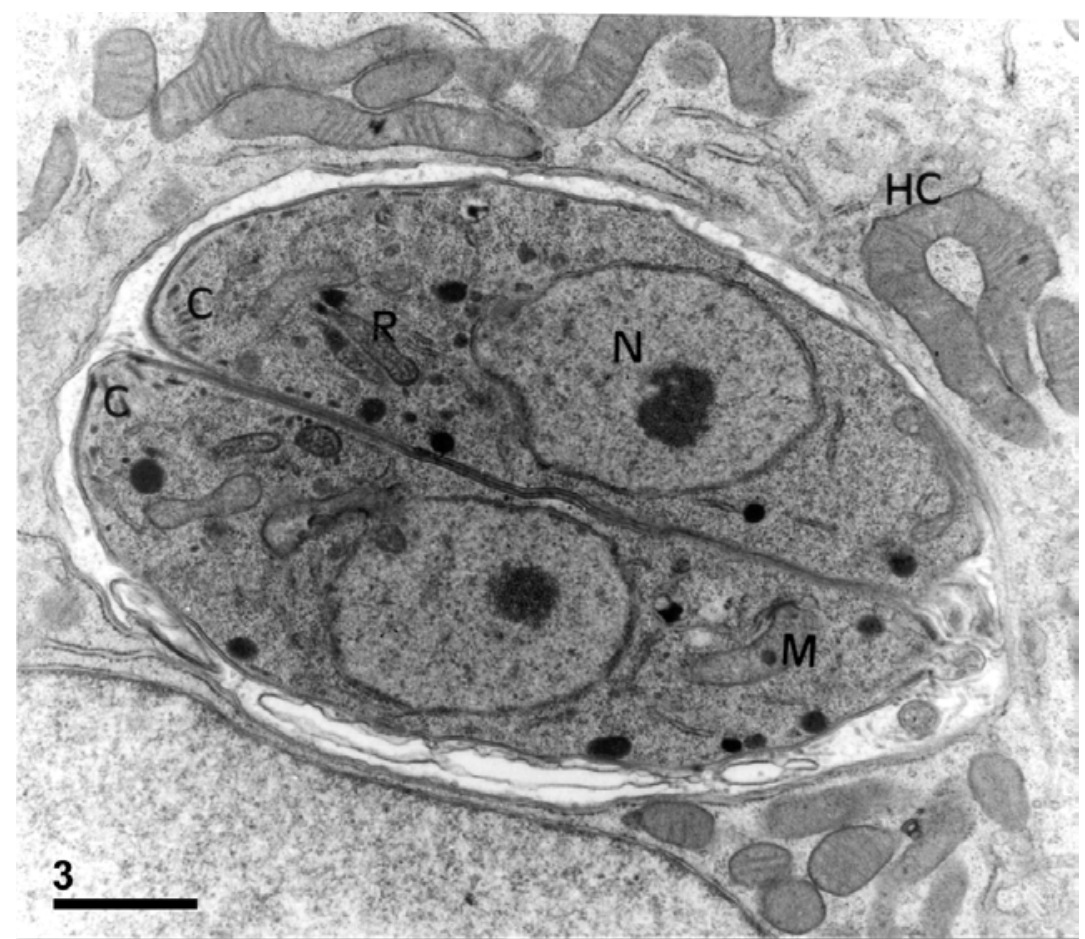

Fig. 3 - Two trophozoites of Toxoplasma gondii within the parasitophorous vacuole. C, conoid; HC, host cell; M, mitochondrion; N, nucleus; R, rhoptries. Bar, $0.4 \mu \mathrm{m}$.

the rhoptry of T. gondii (Karasov et al. 2005). This protein may be involved in rhoptry $\mathrm{pH}$ regulation. This organelle presents as a characteristic feature the fact that when its lipids and proteins are exocytosed through the duct the organellar membrane is retained and an empty organelle, which can be easily identified by electron microscopy, remains.

Immunocytochemistry provided evidence that the rhoptry content is not homogeneous. For instance, some proteins are localized in the basal region of the organelle whereas others are located in its apical portion (Review in Blackman and Bannister 2001).

Secretion of rhoptry proteins takes place immediately after adhesion of the parasites to the host cell surface. In the case of $T$. gondii kinetic studies showed that release of the proteins is completed in about 1 minute and that the proteins are internalized and will make part of the membrane lining the parasitophorous vacuole (Sam-Yellowe et al. 1988, Saf- fer et al. 1992, Carruthers and Sibley 1997). Several rhoptry proteins have been identified and characterized. ROP1 has a size of $60 \mathrm{kDa}$ and exhibits an extreme charge asymmetry with a highly acidic $\mathrm{N}$ terminal domain and a basic $\mathrm{C}$-terminal domain suggesting that it participates in protein-protein interactions (Ossorio et al. 1992). It has been suggested (Schwartzman 1986) that ROP1 corresponds to the penetration enhancing factor previously characterized in T. gondii (Lycke et al. 1968) and for some time it was considered as a key molecule for the penetration of host cells by this parasite. However, it was shown that ROP1 null mutants invade host cells normally (Kim and Boothroyd 1993). ROP2, which has a size of $54 \mathrm{kDa}, \mathrm{ROP} 3, \mathrm{ROP} 4$ and ROP8 are antigenically cross-reactive and may have overlapping functions. ROPs 2 and 8 have been characterized in some detail and cDNA sequences have shown that although they are highly homologous with one another they share no significant homol- 
ogy with any other proteins in the databases (Beckers et al. 1994, 1997). Both possess single putative transmembrane segments 75 amino acids from their respective $\mathrm{C}$-termini. OP2 is secreted during the process of penetration of $T$. gondii into the host cell and is found in association with the membrane lining the parasitophorous vacuole. Its N-terminal domain is exposed on the cytoplasmic face of the parasitophorous vacuole and may be involved in the association of the vacuoles with cytoplasmic organelles of the host cell such as the endoplasmic reticulum and mitochondria (Sinai et al. 1997, Sinai and Joiner 2001). Little is known about the other ROP proteins, which have been identified using monoclonal antibodies (Leriche and Dubremetz 1991). A novel rhoptry protein, designated as BRP1, was recently identified in nascent organelles found during the first division of bradizoites, but not in tachyzoites (Schwarz et al. 2005).

The rhoptries of $T$. gondii have been isolated by subcellular fractionation procedures and biochemical analysis showed a lipid to protein ratio of 0.26 , thus indicating their richness in proteins. The cholesterol to phospholipid ratio was 1.48. Phosphatidylcholine was the major phospholipid (Foussard et al. 1991). Proteomic analysis using mass spectrometry of the fraction identified 38 novel proteins. At least 11 of them were localized in the rhoptries, as shown by immunofluorescence microscopy. Some are localized in the bulbous basal portion of the organelle while others are restricted to the neck portion, an observation which points to the existence of different domains in the rhoptries. In addition other proteins such as toxofilin, Rab 11, kinases and phosphatases were also found in the rhoptry (Bradley et al. 2006).

The rhoptries isolated from $P$. falciparum merozoites showed a large number of proteins (Etzion et al. 1991). A large number of rhoptry proteins have been identified in Babesia, Plasmodium and Eimeria (Review in Sam-Yellowe 1999). Many of them present as a special feature the ability to bind to erythrocytes.

\section{Dense GRanules}

The dense granules are spherical organelles distributed throughout the cell rather than localized at the apical complex, with a mean diameter of $0.2 \mu \mathrm{m}$ (Fig. 4). Its matrix is uniformly electron dense due to the high concentration of protein. Kinetic studies have shown that secretion of the dense granule content takes place after parasite invasion and localization within the parasitophorous vacuole persisting for several minutes (Carruthers and Sibley 1997). In contrast to secretion of micronemes and rhoptries, which takes place in the apical region, dense granule secretion occurs at the lateral regions of the protozoan. The secreted proteins associate with the membrane of the parasitophorous vacuole and with the parasite derived intravacuolar membranous network. Proteins are delivered to the dense granule by the bulk flow pathway (Coppens et al. 1999). Proteins from which specific targeting signals for other organelles have been deleted are localized in the dense granules (Striepen et al. 2001, Reiss et al. 2001).

Several proteins have been identified in the dense granules. GRA1 has a size of 22-27 kDa is relatively abundant and remains either soluble within the vacuole or loosely associated to the membranous network. It binds $\mathrm{Ca}^{2+}$ with two $\mathrm{EF}$ hand motifs and therefore has been considered to be involved in homeostasis of this ion within the vacuole (Cesbron-Delauw et al. 1989). GRA2 has a size of $28.5 \mathrm{kDa}$ and after secretion is tightly associated with the membranous network (Mercier et al. 1993, 1998a) through two amphiphatic alpha-helical domains (Mercier et al. 1998a, Sibley et al. 1995). The expression of an HA9 epitope-tagged form of GRA2 by stable transformation of $T$. gondii showed that it is correctly packaged secreted and targeted. Expression of deletion mutants lacking either of two amphiphatic alpha helices resulted in the production and secretion of proteins, which did not associate in a stable way to the membranous network (Mercier et al. 1998b). Based on the observation that a GRA2 null mutant of $T$. gondii presents an 


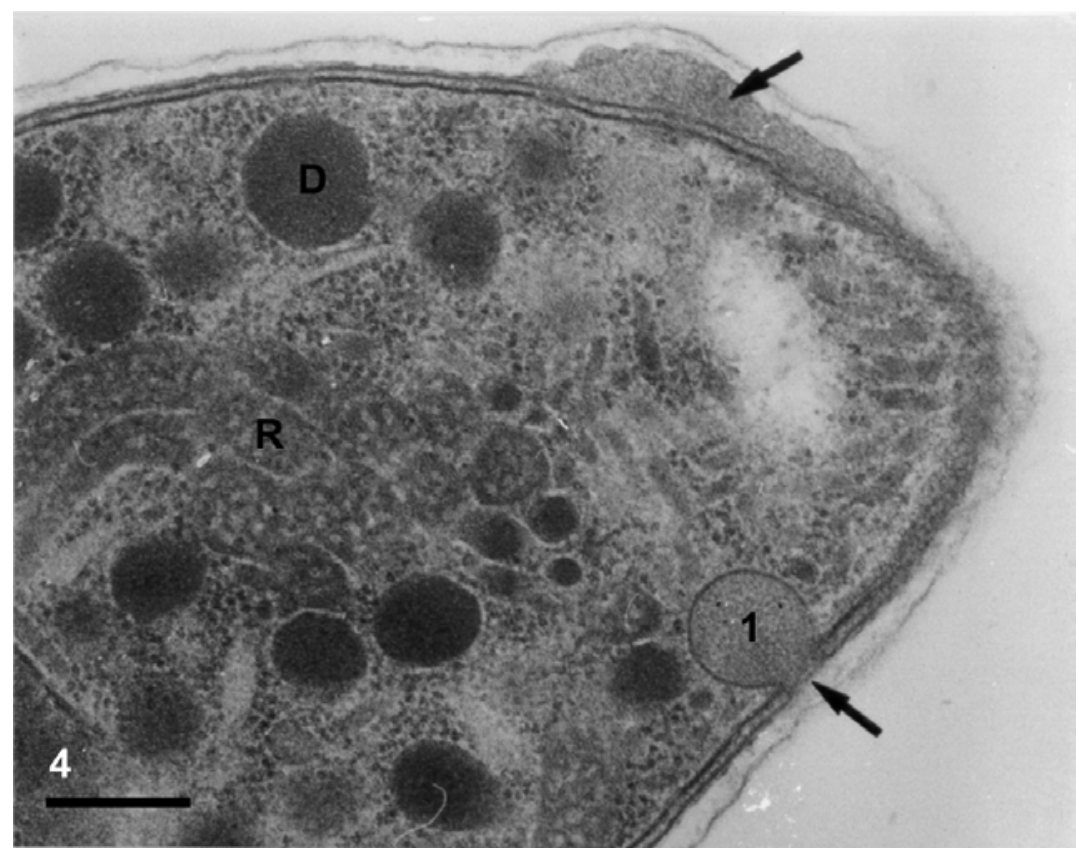

Fig. 4 - Secretion of the dense granule content (arrows) in the lateral side of the tachyzoite form of Toxoplasma gondii. D, dense granules; R, rhoptries. Bar, $0.35 \mu \mathrm{m}$. Courtesy of JF Dubremetz.

attenuated virulence to mice it has been suggested that this protein plays some role in the virulence of the parasite (Mercier et al. 1998b). GRA3 has a size of $30 \mathrm{kDa}$ and forms multimeric complexes that associate with the membrane lining the vacuole through hydrophobic interactions (Ossorio et al. 1994), although there is no predicted membranespanning domain for it. However, it was recently shown that GRA3 is actually an artificial chimera of 2 proteins. One, with a molecular weight of $65 \mathrm{kDa}$, shares the C-terminus of GRA3 and the other, with a predicted molecular weight of $24 \mathrm{kDa}$, shares the $\mathrm{N}$-terminal region and is recognized by antibodies previously shown to label the dense granules. The corrected GRA3 has a N-terminal secretory signal sequence and a transmembrane domain, which explains its insertion into the membrane lining the parasitophorous vacuole (Henriquez et al. 2005).

GRA 4, 5, 6, 7 and 8 each have one putative transmembrane segment and it has been suggested that they may constitute the molecular sieve that allows the passage of molecules smaller than
$1900 \mathrm{Da}$ across the vacuolar membrane (Schwab et al. 1994). These proteins have a size in the range of 21 to $32 \mathrm{kDa}$. The level of GRA 7 expression is lower in a less virulent strain of $T$. gondii. An additional form of GRA 7 with reduced mobility, probably due to some modification of the protein after exocytosis, was detected on the surface of intact host cells (Neudeck et al. 2002). How this protein reaches the host cell surface is not yet clear. More recently a new protein, designated as GRA 9, was identified. It is a $41 \mathrm{kDa}$ protein, which associates with the tubular network found within the PV (Adjogble et al. 2004). In addition to the GRA series the dense granules also contain two closely related isoenzymes of the nucleotide triphosphatase NTPase which are involved in breaking down host-supplied di- and triphosphate nucleotides participating in the purine salvage pathway, for which T. gondii is auxotrophic (Asai et al. 1983, 1995, Sibley et al. 1994) and in the initiation of the release of the parasites from the vacuole (Stommel et al. 1997, Silverman et al. 1998) in a process which in- 


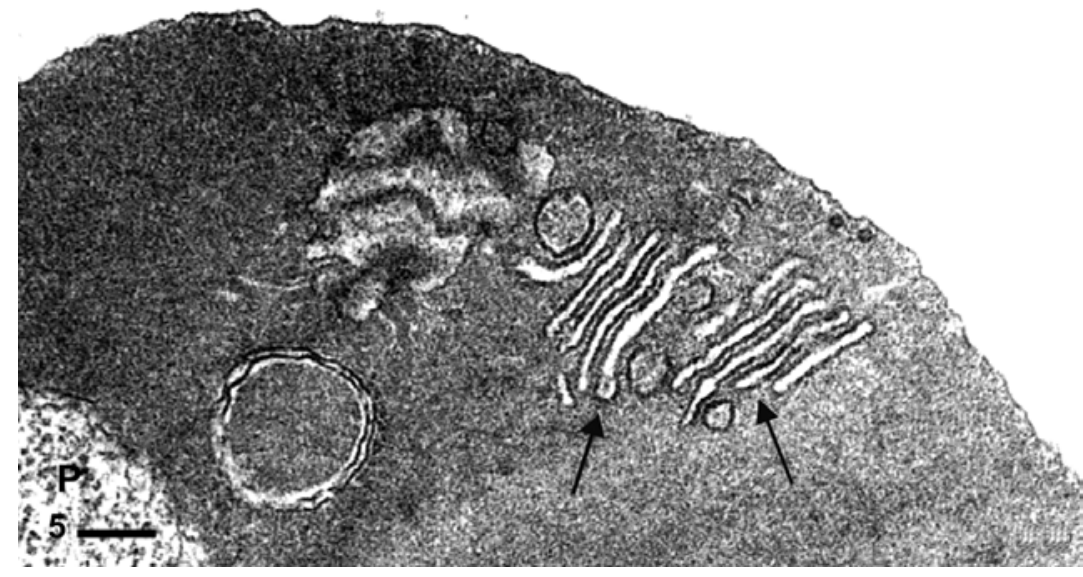

Fig. 5 - Stack of flattened lamellae (arrows), which form the Maurer's cleft found in erythrocytes, infected with Plasmodium falciparum. P, parasite. Bar, $0.25 \mu \mathrm{m}$. After Przyborski et al. 2003.

volves depletion of ATP and increase in $\mathrm{Ca}^{2+}$ concentration (Stommel et al. 1997, Silverman et al. 1998). Two protease inhibitors have also been identified in the dense granules (Morris et al. 2002, Pszenny et al. 2002).

\section{THE MAURER'S CLEFT IN PLASMODIUM}

Erythrocytes infected by P. falciparum show the presence of a cytoplasmic structure, which is labeled when the cells are incubated in the presence of anti-malaria antibodies, and observed by fluorescence microscopy (Tobie and Coatney 1961). Transmission electron microscopy of thin sections of infected erythrocytes revealed the presence of stacks of flattened lamelae of long slender membranes with a translucent lumen, usually located below the erythrocyte plasma membrane, and designated as Maurer's cleft (Fig. 5) (Trager et al. 1966, Langreth et al. 1978). Variable aspects of this structure have been extensively described in several Plasmodium species (Review in Przyborski et al. 2003, Lanzer et al. 2006). This structure has not been observed in other members of the Apicomplexa group.

Several parasite proteins have been shown to be localized in the Maurer's cleft. They are synthesized in the parasite ER and then transferred to the cleft (Blisnick et al. 2005, Marti et al. 2005).
Subsequently they are transported to the erythrocyte surface. For some authors the Maurer's cleft is a well defined structure continuously supplied with vesicles budding of from the membrane lining the parasitophorous vacuole. Subsequently, vesicles bud of from the cleft and migrate towards the erythrocyte cell surface, with secretion of their contents into the medium and incorporation of some proteins in the erythrocyte plasma membrane. Vesicles with a diameter of $100 \mathrm{~nm}$ have been identified in infected erythrocytes. Homologues of COPI and COPII proteins, which have been shown to play an important role in transport of vesicles in mammalian cells, were identified in P. falciparum (Adisa et al. 2002, Wickert et al. 2003). Other groups consider that the Maurer's cleft is part of a continuous network that connects the PV to the erythrocyte cell surface. This view, based on images obtained by confocal laser scanning microscopy, has been confirmed by three-dimensional reconstruction of thin sections (Wickert et al. 2003). According to this view the secretory route would include insertion of proteins in the PV membrane, which then would move along the membrane network by lateral diffusion. Only at the end of these tubular network vesicles would they bud and fuse with the erythrocyte plasma membrane. A recent review covers 
well the process of protein transport and trafficking in Plasmodium falciparum-infected erythrocytes (Przyborski and Lanzer 2005). Another recent review (Marti et al. 2005) analyses the functional role played by several parasite proteins which concentrates in the Maurer's cleft and are involved in processes such as cytoadherence and import of serum proteins.

\section{CELL SECRETION IN TRYPANOSOMATIDS}

Members of the Trypanosomatidae family present a well developed endoplasmic reticulum-Golgi complex system with the formation of coated and uncoated vesicles which subsequently migrate towards a specialized and polarized region of the cell surface, known as the flagellar pocket, where they fuse with the membrane (Figs. 6-7) (Reviews in De Souza 1984, Landfear and Ignatushchenko 2001). The flagellar pocket corresponds to a specialized region where most of the endocytic and exocytic activities take place in the trypanosomatids. It is important to point out that the secretory vesicles do not present a dense content and for this reason they are not easily distinguished from the endocytic vesicles which form at the flagellar pocket region and are involved in the uptake of important macromolecules or macromolecular complexes such as transferring and LDL. At least three distinct groups of secretory products have been identified in trypanosomatids based on their fate: (a) one group contains integral or peripheral proteins which are inserted into the flagellar pocket and subsequently migrates to other regions of the plasma membrane. The most evident examples include the synthesis and secretion of the variant surface proteins (VSGs) found in bloodstream forms of Trypanosoma brucei and which is involved in the process of antigenic variation (Review in Borst et al. 1998) and cysteine proteinase (cruzin or cruzipain) T. cruzi (Fig. 8) (Souto-Padrón et al. 1990); (b) The second group are accumulated in special organelles, as the megasomes of Leishmania (Figs. 9-10); (c) the third group includes proteins that are released into the flagellar pocket where they remain as sol- uble proteins, as is the case of cysteine proteinase (Fig. 11) and proteophosphoglycans in Leishmania (Duboise et al. 1994, Foth et al. 2002), while others polymerize within the pocket, as is the case of acid phosphatase found in Leishmania (Stierhof et al. 1994). How these different proteins are sorted is not yet clarified. Studies carried with $T$. brucei have shown that VSG lacking its GPI anchor is not efficiently secreted. The proteins may be then mistargeted to the lysosome and is subsequently degraded (Triggs and Bangs 2003).

\section{CELL SECRETION IN GIARDIA}

As in all eukaryotic cells, trophozoites of Giardia lamblia synthesize proteins, which are incorporated into its plasma membrane as well as are secreted into the medium. These proteins are synthesized in the endoplasmic reticulum. Ultrastructural and cytochemical studies have shown that this protozoan does not present a typical Golgi complex system, although structures resembling this organelle can be occasionally seen (Lujan et al. 1995a, LanfrediRangel et al. 1999, Marti et al. 2003, McCaffery et al. 1994). Certainly the more elaborated secretory system in Giardia occurs during the process of transformation of the trophozoites into cystic forms, when there is formation of a cyst wall (Review in Marti and Hehl 2003). This process plays a fundamental role in the life cycle of the parasite allowing the development of forms which resist to drastic environmental conditions. Several studies have shown that cyst wall proteins are synthesized in an area of the endoplasmic reticulum where the cisternae is modified, forming a dilated region known as the cleft (Lujan et al. 1995b, Lanfredi-Rangel et al. 2003, Gillin et al. 1996) (Figs. 12-13). Apparently there is no participation of the Golgi complex in this process. The cleft is continuous with the endoplasmic reticulum and lacks an electron dense content. Gradually the cleft widen and become filled with a homogeneously dense material formed by the concentration of the cyst wall proteins (CWP) (Figs. 13-14), as can be shown by immunocytochemical 


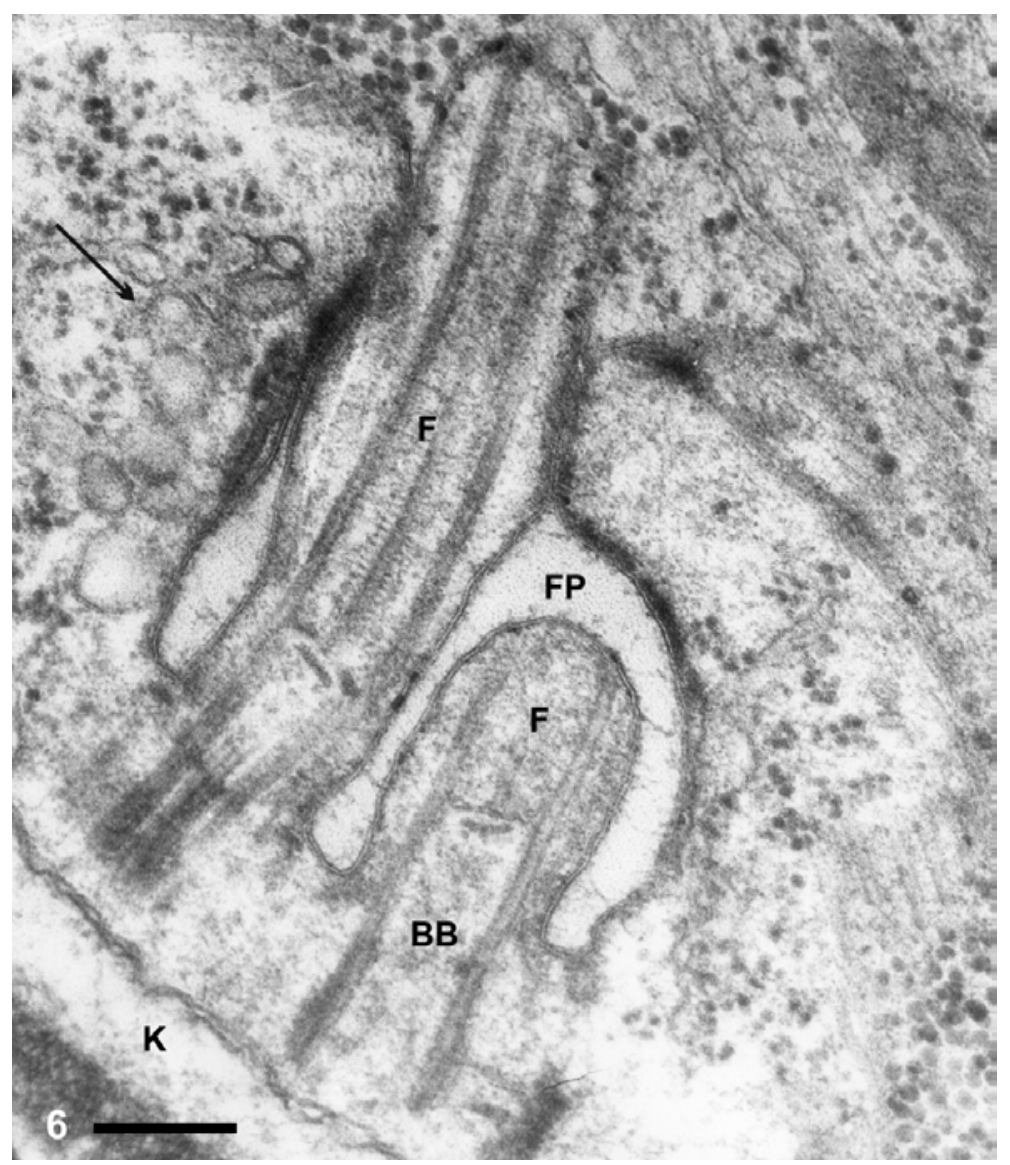

Fig. 6-Anterior region of an amastigote form of Trypanosoma cruzi showing the flagellar pocket (FP), two short flagella (F), the basal body (BB) and the kinetoplast (K). Vesicles are seen close to the flagellar pocket (arrow). Bar, $0.25 \mu \mathrm{m}$.

localization of these proteins. Although continuity of this structure with the ER is evident, glucose-6phophatase, a classical enzyme marker of the ER, is no more found in this structure (Lanfredi-Rangel et al. 2003). Subsequently the dense vesicle, which is now designated as an encystation vesicle (ESV), increases in density (Figs. 15-17) and migrates towards the periphery of the cell (Figs. 18-19). Another view of the process suggests that ER vesicles containing CWP use to each other to form the ESV (Marti and Hehl 2003, Marti et al. 2003). Analysis of the genome data on G. lamblia led to the identification of orthologs to factors involved in vesicle tethering and fusion, as soluble N-ethyl-maleimide- sensitive fusion proteins, Sec-1 adapters, Rabs and the COPI complex. Two syntaxin homologs and two Rab GTPases, designed as Rab 1 and Rab 2, were identified (Marti et al. 2003).

At the cell periphery, the ESV establishes contact both with the inner portion of the plasma membrane of the trophozoites as well as with the peripheral vesicles, acidic organelles that correspond to an endosome-lysosome system (Lanfredi-Rangel et al. 1998). The observation that cyst wall proteins are processed by a cysteine proteinase localized in the peripheral vesicles (Touz et al. 2002), suggests that fusion of the ESV with the peripheral vesicles takes place immediately before or simultaneously 


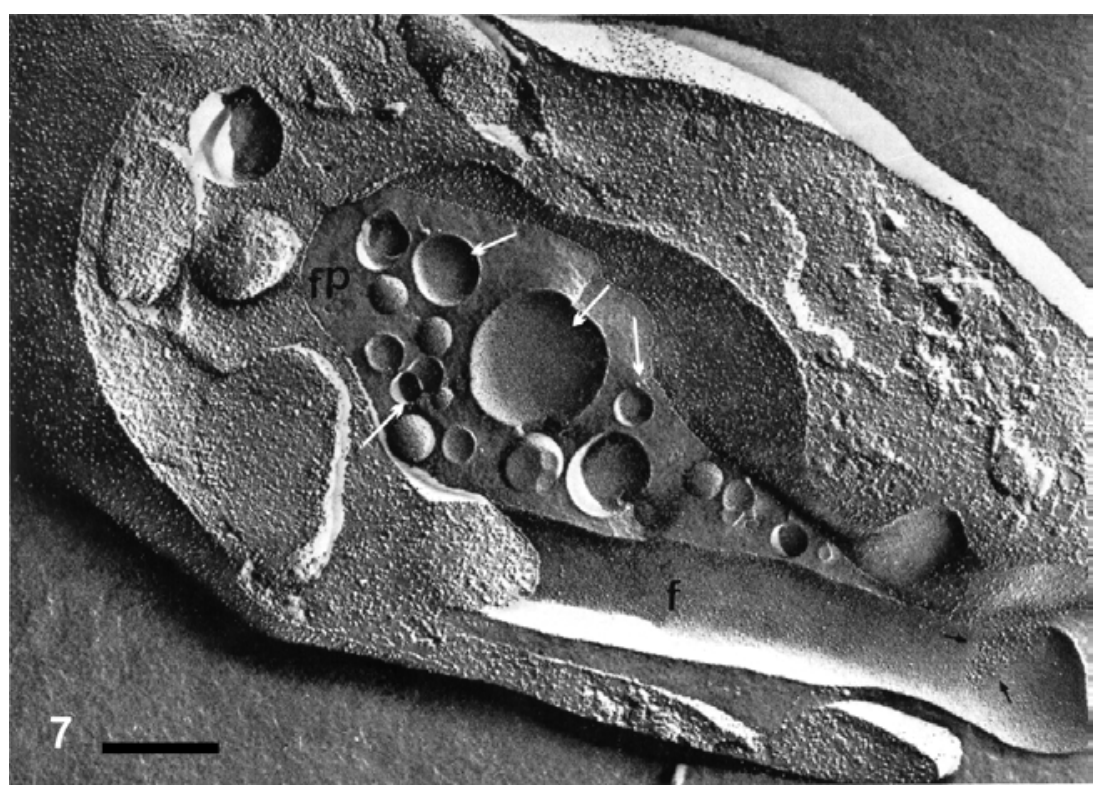

Fig. 7 - Freeze-fracture view of the anterior region of a promastigote forms of Herpetomonas. A large number of vesicles (arrows) are seen within the flagellar pocket (FP). F, flagellum. Small arrows point to an aggregation of intramembranous particles, which form the flagellar-cell body adhesion structure. Bar, $0.12 \mu \mathrm{m}$. After De Souza et al. 1979.

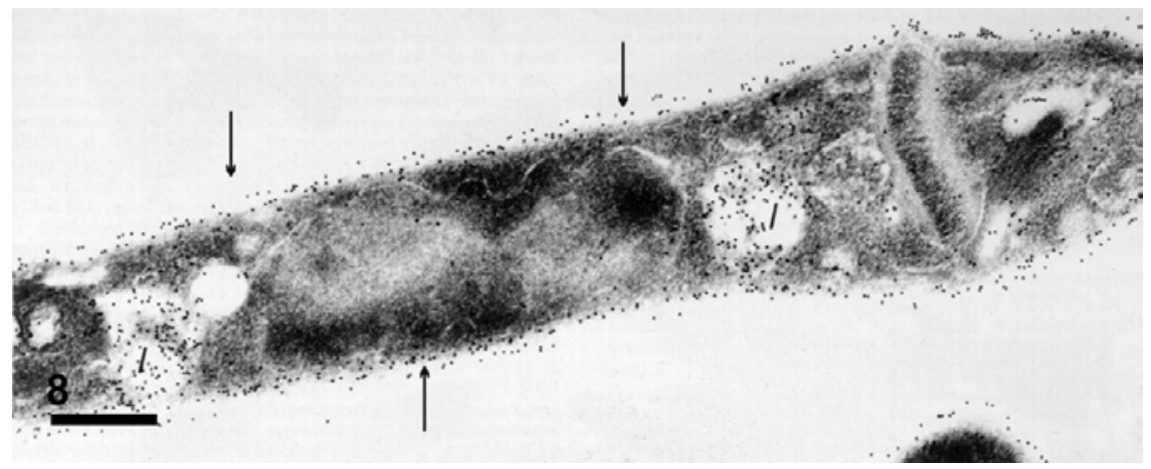

Fig. 8 -Immunocytochemical localization of cysteine proteinase in epimastigotes of Trypanosoma cruzi. This protein is synthesized in the ER and concentrated in structures which are part of the endocytic pathway of this protozoan (asterisks) and in the plasma membrane (arrows). Bar, $0.5 \mu \mathrm{m}$. After Souto-Padrón et al. 1990.

with the fusion of the ESV with the cell surface. It is important to point out that the cyst wall proteins are not glycosylated but they have potential $\mathrm{N}$ - and O-glycosylation sites (Lujan et al. 1995b, Mowatt et al. 1995). It has been considered that the cyst wall, which is formed by interconnected fil- aments containing peptides and carbohydrate moieties (Manning et al. 1992), is assembled as consequence of exocytosis of the encystation vesicles (Erlandsen et al. 1996, Gillin et al. 1991, 1996). For some authors there is a dispersal of ESV into small secretory vesicles before secretion (Marti and Hehl 


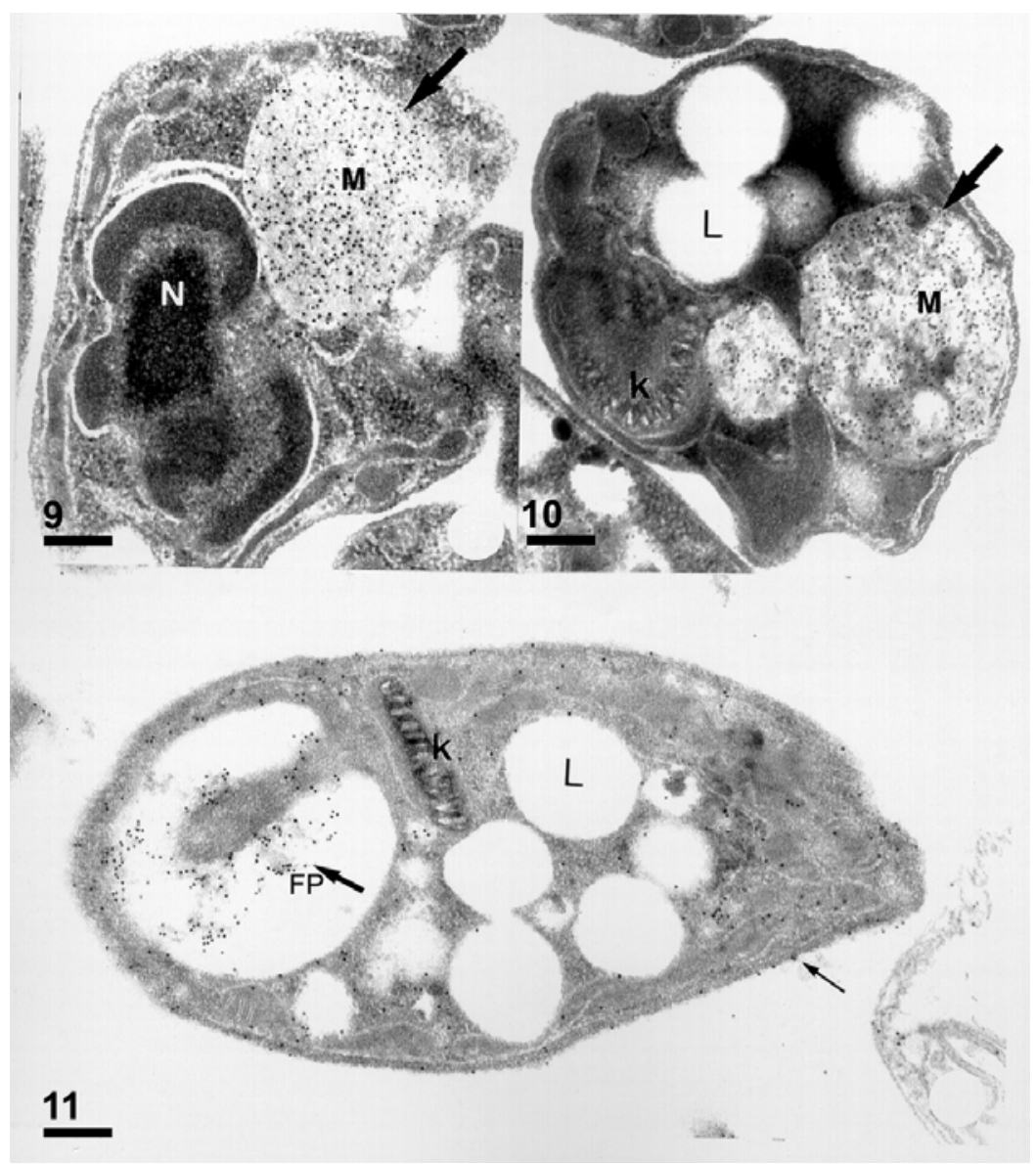

Figs. 9-11 - Immunocytochemical localization of cysteine proteinase in amastigotes of Leishmania amazonensis. This protein is stored in the megasomes (M) and secreted into the flagellar pocket. Labeling of the cell surface (arrow in figure 11) and of the cisternae of the endoplasmic reticulum is observed. FP, flagellar pocket; K, kinetoplast; L, lipidic inclusion; M, megasome. Bar, $0.25 \mu \mathrm{m}$. Micrographs from T Ueda-Nakamura and W de Souza.

2003). More recently it was suggested that a typical exocytosis does not occur. During membrane fusion some membrane segments appeared to be disrupted and released into the extracellular medium where could be resealed forming empty vesicles (Benchimol 2004).

During the period of encystation G. lamblia maintains a constitutive pathway for the synthesis of the variant surface proteins. These proteins are not mixed with the ESV proteins. Therefore, the protozoan may have sorting mechanisms to distinguish these two export pathways.

\section{CELL SECRETION IN ENTAMOEBA}

Members of the Entamoeba genus synthesize several proteins, which are secreted. Cisternae of the endoplasmic reticulum and a putative Golgi have been identified by confocal microscopy of cells labeled with NBD-ceramide ands by transmission electron microscopy (Mazzuco et al. 1997). Biochemical and molecular studies have shown the presence of an endoplasmic reticulum retention receptor ERD2, a cis-Golgi-associated transmembrane protein (Sanchez-Lopez et al. 1998). BiP, 

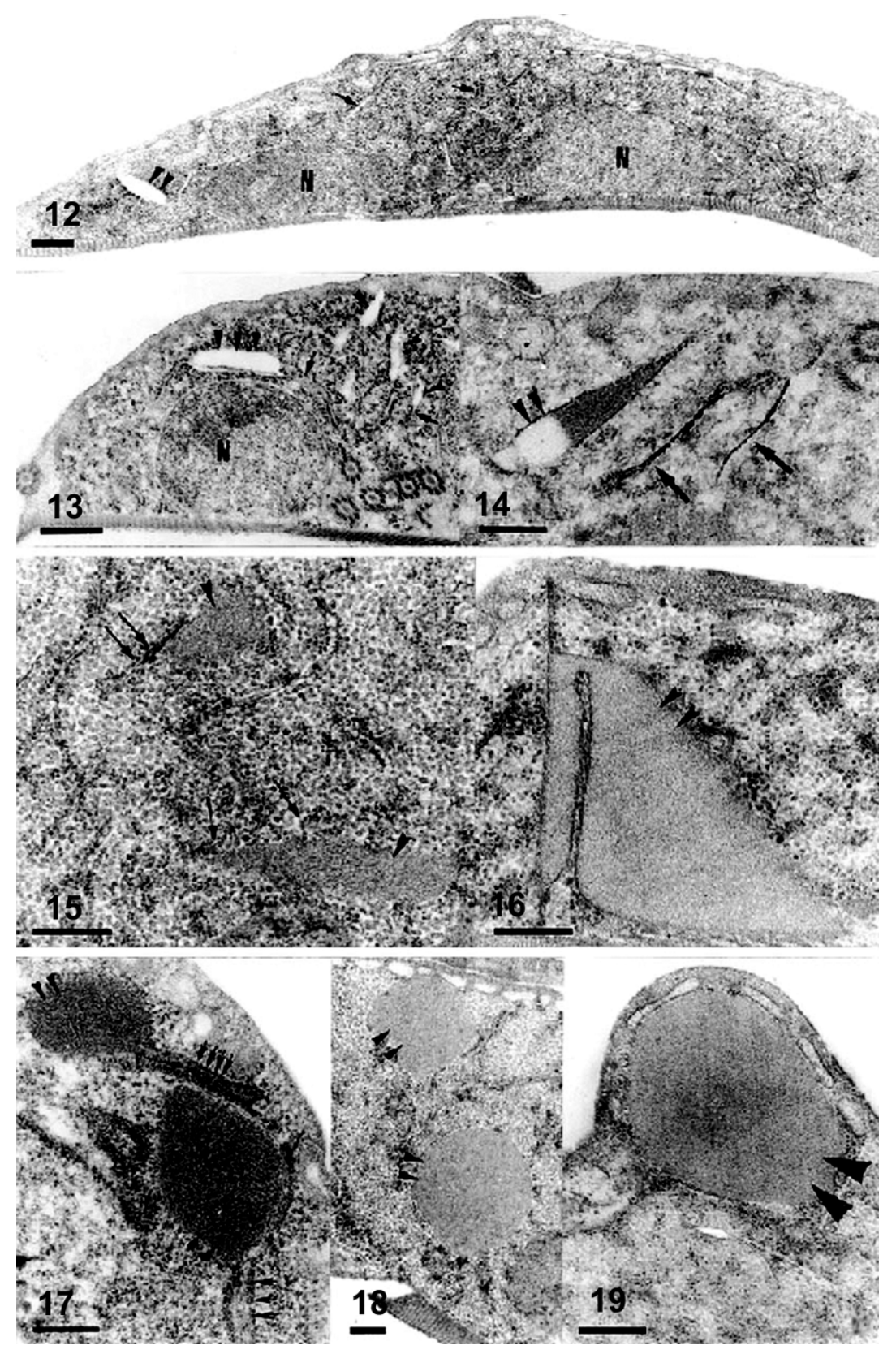

Figs. 12-19 - Different stages of the process of biosynthesis of cyst wall proteins during encystation of Giardia lamblia. The process starts with the formation of clefts in the endoplasmic reticulum (arrows in figure 12), accumulation of dense material within the clefts (arrows in Figs. 13-14), with the formation of encystation vesicles (Figs. 14-17) which then migrates towards the cell periphery (Figs. 17-19). N, nucleus. Bars, $0.4 \mu \mathrm{m}$. After Lanfredi-Rangel et al. 2003. 
a known marker of the ER, has also been identified in E. histolytica (Ghosh et al. 1999). Proteins present on the surface of E. histolytica, as the Serrich protein and the Gal or GalNAc lectin are inserted into the plasma membrane via fusion of secretory vesicles to the membrane. During the process of encystation, which has been studied mainly in E. invadens, proteins such as chitinase, localized using an immunocytochemical approach, were seen in many secretory vesicles (Ghosh et al. 1999). During encystation of E. histolytica trophozoites large vacuoles with a densely packed filamentous content were observed. They contained chitin since were labeled when cells were incubated in the presence of calcofluor (Chávez-Munguía et al. 2004). It was suggested that these vacuoles are equivalent to the encystation vesicles described during encystation of G. lamblia.

\section{ACKNOWLEDGMENTS}

The work carried out in the author's laboratory has been supported by Conselho Nacional de Desenvolvimento Científico e Tecnológico (CNPq), Fundação Carlos Chagas Filho de Amparo à Pesquisa do Estado do Rio de Janeiro (FAPERJ) and Programa de Núcleos de Excelência (PRONEX).

\section{RESUMO}

Processos de secreção celular desempenham papel relevante na biologia e no ciclo de vida de protozoários patogênicos. A presente revisão analisa, sob uma perspectiva de biologia celular, o processo de secreção em (a) micronemas, roptrias e grânulos densos encontrados em membros do grupo Apicomplexa, onde essas estruturas participam da penetração do protozoário no interior da célula hospedeira, na sua sobrevivência intravacuolar e no posterior egresso da célula hospedeira, (b) a fenda de Maurer, encontrada em Plasmodium, uma estrutura envolvida na secreção de proteínas sintetizadas pelo protozoário intravacuolar e transportada, através de vesículas, para a superfície do eritrócito, (c) a secreção de macromoléculas na bolsa flagelar de tripanosomatídeos, e (d) a secreção de proteínas que fazem parte da parede cística de
Giardia e Entamoeba e que se concentram nas vesículas de encistamento.

Palavras-chave: protozoários parasitas, secreção celular, apicomplexa, tripanosomatídeos, vesículas de encistamento.

\section{REFERENCES}

Achbarou A, Mercereau-Puijalon O, AutherMAN JM, Fortier B, CAMUS D AND DUBReMETZ JF. 1991. Characterization of microneme proteins of Toxoplasma gondii. Mol Biochem Parasitol 47: 223-234.

Adisa A, Rug M, Foley M ANd Tilley L. 2002. Characterization of a delta-COP homologue in the malaria parasite, Plasmodium falciparum. Mol Biochem Parasitol 123: 11-21.

Adjogble KDZ, Mercier C, Dubremetz JF, Hucke C, Mackenzie CR, Cesbron-Delaw MF AND DAUBENER W. 2004. GRA 9, a new Toxoplasma gondii dense granule protein associated with the intravacuolar network of tubular membranes. Int J Parasitol 34: 1255-1264.

Arrizabalaga G AND Boothroyd JC. 2004. Role of calcium during Toxoplasma gondii invasion and egress. Int J Parasitol 34: 361-368.

Asai T, O’Sullivan WJ And Tatibana M. 1983. A potent nucleoside triphosphate hydrolase from the parasitic protozoan Toxoplasma gondii. J Biol Chem 258: 6816-6822.

Asai T, MiUra S, Sibley LD, OKABAyAshi H AND TAKEUCHI T. 1995. Biochemical and molecular characterization of nucleosidase triphosphate hydrolase isoenzymes from the parasitic protozoan Toxoplasma gondii. J Biol Chem 270: 11391-11397.

Barragan A, Brossier F AND Sibley LD. 2005. Transepithelial migration of Toxoplasma gondii involves an interaction of intercellular adhesin molecule 1 (ICAM-1) with the parasite adhesin MIC2. Cell Microbiol 7: 561-568.

Becker B And Melkonian M. 1996. The secretory pathway of protists: spatial and functional organization and evolution. Microbiol Rev 60: 697-721.

Beckers CJM, Dubremetz JF, MercereauPUIJALON O AND JoIner KA. 1994. The Toxoplasma gondii rhoptry protein ROP2 is inserted into 
the parasitophorous vacuole membrane, surrounding the intracellular parasite, and is exposed to the host cell cytoplasm. J Cell Biol 127: 947-961.

BeCKERS CJM, WAKEWFIELD T AND JOINER KA. 1997. The expression of Toxoplasma proteins in Neosporum caninum and the identification of a gene encoding a novel rhoptry protein. Mol Biochem Parasitol 89: 209-223.

BENCHIMOL M. 2004. The release of secretory vesicle in encystation Giardia lamblia. FEMS Microbiol Lett 235: 81-87.

Blackman MJ And BAnNister LH. 2001. Apical organelles of Apicomplexa: biology and isolation by subcellular fractionation. Mol Biochem Parasitol 117: 11-25.

Blisnick T, Vincensini L, Barale JC, Namane A AND BRETON CB. 2005. LANCL1, an erythrocyte protein recruited to the Maurer's clefts during Plasmodium falciparum development. Mol Biochem Parasitol 141: 39-47.

Borst P, Bitter W, Blundell PA, Chaves I, Cross M, Gerrits H, van Leeuwen F, McCulloch R, TAYlor M and RudenKo G. 1998. Control of VSG gene expression sites in Trypanosoma brucei. Mol Biochem Parasitol 91: 67-76.

Bouchot A, Zierold K, Bonhomme A, Kilian L, Belloni A, BAlossier G, PinON JM AND BonHOMME P. 1999 Tachyzoite calcium changes during cell invasion by Toxoplasma gondii. Parasitol Res 85: 809-818.

BRAdley PJ AND Boothroyd JC. 2001. The pro region of Toxoplasma ROP1 is a rhoptry-targeting signal. Int J Parasitol 31: 1177-1186.

BRAdLey PJ ET AL. 2006. Proteomic analysis of rhoptry organelles reveals many novel constituents for host-parasite interaction in Toxoplasma gondii. J Biol Chem 280: 34245-34258.

Brecht S, Carruthers VB, Ferguson DJ, GidDings OK, WANG G, JACKLE U, HARPER JM, Sibley LD AND Soldati D. 2001. The toxoplasma micronemal protein MIC4 is an adhesin composed of six conserved apple domains. J Biol Chem 276: 4119-4127.

Brossier F, Jewett TJ, Lovett JL AND Sibley LD. 2003. C-terminal processing of the Toxoplasma protein MIC2 is essential for invasion into host cells. J Biol Chem 278: 6229-6234.

Brossier F, Jewett TJ, Sibley LD AND URbaN S. 2005. A spatially localized rhomboid protease cleaves cell surface adhesions essential for invasion by Toxoplasma. Proc Natl Acad Sci USA 102: 41464151.

BRYdGes SD, SHERMAN GD, NOCKEMANN S, Loyens A, DAubner W, Dubremetz JF AND CARruthers VB. 2000. Molecular characterization of TgMIC5, a proteolitically processed antigen secreted from the micronemes of Toxoplasma gondii. Mol Biochem Parasitol 111: 51-66.

Carruthers VB and Sibley LD. 1997. Sequential protein secretion from three distinct organelles of Toxoplasma gondii accompanies invasion of human fibroblasts. J Cell Biol 73: 114-123.

Carruthers VB and Sibley LD. 1999. Mobilization of intracellular calcium stimulates microneme discharge in Toxoplasma gondii. Mol Microbiol 31: 421-428.

Carruthers VB, Giddings OK and Sibley LD. 1999a. Secretion of micronemal proteins is associated with toxoplasma invasion of host cells. Cell Microbiol 1: 225-235.

Carruthers VB, Moreno SNJ ANd Sibley LD. 1999b. Ethanol and acetaldehyde elevate intracellular $\mathrm{Ca}^{2+}$ and stimulate microneme discharge in Toxoplasma gondii. Biochem J 342: 379-386.

CARruthers VB, Sherman GD AND Sibley LD. 2000. The Toxoplasma adhesive proteins MIC2 is proteolitically processed at multiple sites by two parasite-derived proteases. J Biol Chem 275: 1434614353.

CARvalho TU, Souto-Padrón T AND DE Souza W. 1991. Localization of lectin-binding sites and sugar-binding proteins in tachyzoites of Toxoplasma gondii. J Parasitol 77: 156-161.

Cérède O, Dubremetz JF, Soête M, Deslée D, Vial H, Bout D and Lebrun M. 2005. Synergistic role of micronemal proteins in Toxoplasma gondii virulence. J Exp Med 201: 453-463.

Cesbron-Delauw MF et AL. 1989. Molecular Characterization of a 23-Kilodalton $\mathrm{K}$ major antigen secreted by Toxoplasma gondii. Proc Natl Acad Sci USA 86: 7537-7541. 
Chávez - Munguía B, Hernández - Ramírez V, Ángel A, Ríos A, TALAMÁs-RoHANA P, GONZÁleZ-Robles A, GonZÁleZ-LÁZARo M AND MARíneZ-PALOMO A. 2004. Entamoeba histolytica: ultrastructure of trophozoites recovered from experimental liver lesions. Exp Parasitol 107(1-2): $39-46$.

Coppens I, Andries M, LiU JL And CesbronDELAUW MF. 1999. Intracellular trafficking of dense granule proteins in Toxoplasma gondii and experimental evidences for a regulated exocytosis. Eur J Cell Biol 78: 463-472.

DE SouZA W. 1984. Cell Biology of Trypanosoma cruzi. Int Rev Cytol 86: 197-283.

DE SouzA W. 2002. Special organelles of some pathogenic protozoa. Parasitol Res 88: 1013-1025.

DE Souza W And Souto-PAdrón T. 1978. Ultrastructural localization of basic proteins on the conoid, rhoptries and micronemes of Toxoplasma gondii. $\mathrm{Z}$ Parasitenkd 56: 123-127.

de Souza W, Chávez B and Martinez-Palomo A. 1979. Freeze-fracture study of the cell membrane of Herpetomonas samuelpessoai. J Parasitol 65: 109-116.

di Cristina M, Spaccapelo R, Soldati D, BisTONI B AND CRISANTi A. 2000. Two conserved amino acid motifs mediate protein targeting to the micronemes of the apicomplexan parasite Toxoplasma gondii. Mol Cell Biol 20: 7332-7341.

Diniz JA, Silva EO, DE Souza W And Lainson R. 2002. Some observations on the fine structure of trophozoites of the haemogregarine Cyrilia lignieresi (Adeleina: Haemogregarinidae) in erythrocytes of the fish Synbranchus marmoratus (Synbranchidae). Parasitol Res 88: 593-597.

Dowse TJ, Pascall JC, Brown KD and Soldati D. 2005. Apicomplexan rhomboids have a potential role in microneme protein cleavage during host cell invasion. Int J Parasitol 35: 747-756.

Duboise SM, VAnNiER-SAntos MA, Costa-Pinto D, Rivas L, Pan AA, Traub-Cseko Y, de Souza W And McMahon-Pratt D. 1994. The biosynthesis, processing and immunolocalization of Leishmania pifanoi amastigote cysteine proteinases. Mol Biochem Parasitol 68: 119-132.
ERlandsen SL, MacechKo PT, KeUlen HV AND JARROL EL. 1996. Formation of the Giardia cyst wall: studies on extracellular assembly using immunogold labeling and high resolution field emission SEM. J Euk Microbiol 43: 416-429.

Etzion Z, Murray MC And Perkins ME. 1991. Isolation and characterization of rhoptries of Plasmodium falciparum. Mol Biochem Parasitol 47: 5162.

Fourmaux MN, Achbarou A, MercereauPuijalon O, Biderre C, Briche I, Loyens A, Odberg-Ferragut C, CAmus D and DubreMETZ JF. 1996. The MIC1 microneme protein of Toxoplasma gondii contains a duplicated receptorlike domain and binds to host cell surface. Mol Biochem Parasitol 83: 201-210.

Foth B, Piani A, Curtis JM, Ilg T, McConville M AND Handman E. 2002. Leishmania major proteophosphoglycans exist as membrane-bound and soluble forms and localize to the cell membrane, the flagellar pocket and the lysosome. Int J Parasitol 32: 1701-1708.

Foussard F, LERICI MA AND DUBREMETZ JF. 1991. Characterization of the lipid content of Toxoplasma gondii rhoptries. Parasitology 102: 367-370.

Ghosh SK, Field J, Frisardi M, Rosenthal B, Mai Z, Rogers R and Samuelson J. 1999. Chitinase secretion by encysting Entamoeba invadens and transfected Entamoeba histolytica trophozoites: localization of secretory vesicles, endoplasmic reticulum and Golgi apparatus. Infect Immu 67: 3073-3081.

GILlin FD, REINER DS AND MCCAFFERY M. 1991. Organelles of protein transport in Giardia lamblia. Parasitol Today 7: 113-116.

GILlin FD, REINER DS AND MCCAFFERY M. 1996. Cell biology of the primitive eukaryote Giardia lamblia. Ann Rev Microbiol 50: 679-705.

HARPER JM, ZHOU XW, PSZENNY V, KAFSACK BFC AND CARRUTHERS VB. 2004. The novel coccidian micronemal protein MIC 11 undergoes proteolytic maturation by sequential cleavage to remove an internal propeptide. Int $\mathrm{J}$ Parasitol 34: $1047-1058$.

HENRiQuez FL, NiCKDEL MB, MCLEOd R, LyONS RE, Lyons K, Dubremetz J-F, GrigG ME, 
SAMUEL BU AND ROBERTS CW. 2005. Toxoplasma gondii dense granule protein 3 (GRA3) is a type I transmembrane protein that possesses a cytoplasmic dilysine (KKXX) endoplasmic reticulum (ER) retrieval motif. Parasitology 131: 169-179.

Hoff EF, Cook SH, Sherman GD, Harper JM, Ferguson DJP, Dubremetz JF AND CARrUTHERS VB. 2001. Toxoplasma gondii: molecular cloning and characterization of a novel 18-KDa secretory antigen, TgMIC10. Exp Parasitol 97(2): $77-88$.

Huynh MH, Barenan Ke, Harper JM, Beatty WL, Sibley LD and Carruthers VB. 2003. Rapid invasion of host cells by Toxoplasma gondii requires secretion of the MIC2-M2AP adhesive protein complex. EMBO J 22: 2082-2090.

Ishino T, Chinzei Y AND YudA M. 2005. A Plasmodium sporozoite protein with a membrane attack complex domain is required for breaching the liver sinusoidal cell layer prior to hepatocyte infection. Cell Microbiol 7: 199-208.

JeWETt TJ AND Sibley LD. 2004. The toxoplasma proteins MIC2 and M2AP form a hexameric complex necessary for intracellular survival. J Biol Chem 279: 9362-9369.

JOINER KA AND Roos DS. 2002. Secretory traffic in the eukaryote parasite Toxoplasma gondii: less is more. J Cell Biol 157: 557-563.

Kaiser K, CAmargo N, Coppens I, Morrisey JM, VAIDYA AB AND KAPPE SHI. 2004. A member of a conserved Plasmodium protein family with membrane-attack complex/perforin (MACPF)-like domains localizes to the micronemes of sporozoites. Mol Biochem Parasitol 133: 15-26.

KARAsov AO, Boothroyd JC AND ARrizabAlaGa G. 2005. Identification and disruption of a rhoptrylocalized homologue of sodium hydrogen exchangers in Toxoplasma gondii. Int J Parasitol 35: 285-291.

KIM K AND Boothroyd JC. 1993. Gene replacement in Toxoplasma gondii with chloramphenicol acetyltransferase as selectable marker. Science 262: 911914.

LANDFEAR SM AND IGNATUSHCHENKO M. 2001. The flagellum and flagellar pocket in trypanosomatids. Mol Biochem Parasitol 115: 1-17.
Lanfredi-Rangel A, Attias M, Carvalho TU, Kattenbach W and de Souza W. 1998. The peripheral vesicles of trophozoites of the primitive protozoon Giardia lamblia may correspond to early and late endosomes and to lysosomes. J Struct Biol 123: 225-235.

LANFredi-RAngel A, Kattenbach W, Diniz JR JA AND DE SouzA W. 1999. Trophozoites of Giardia lamblia may have a Golgi-like structure. FEMS Microbiol Lett 181: 245-251.

Lanfredi-Rangel A, Attias M, Reiner DS, GiLLIN FD AND DE SouZA W. 2003. Fine structure of the biogenesis of Giardia lamblia encystation secretory vesicles. J Struct Biol 143: 153-163.

LANGRETh SG, JENSEN JB, REESE RT AND TRAGER W. 1978. Fine structure of human malaria in vitro. J Protozool 25: 443-452.

LANZER M, Wickert H, Khrone G, VinCENSINI L AND BRETON CB. 2006. Maurer's clefts: a novel multi-functional organelle in the cytoplasm of Plasmodium falciparum-infected erythrocytes. Int J Parasitol 36: 23-36.

LERICHE MA AND DubremetZ JF. 1991. Characterization of the proteins content of rhoptries and dense granule of Toxoplasma gondii tachyzoites by subcellular fractionation and monoclonal antibodies. Mol Biochem Parasitol 45: 249-260.

Lourenço EV, Pereira SR, FaÇa VM, CoelhoCastelo Aam, Mineo JR, Roque-Barreira MC, Green LJ and Panunto-Castelo A. 2001. Toxoplasma gondii micronemal protein MIC1 is a lactose-binding lectin. Glicobiology 11: 541547.

LOVETT JL AND SIBLEY LD. 2003. Intracellular calcium stores in Toxoplasma gondii govern invasion of host cells. J Cell Sci 116: 3009-3016.

Lovett JL, Marchesini N, Moreno SNJ AND SIBLEY LD 2002. Toxoplasma gondii micronemal secretion involves intracellular $\mathrm{Ca}^{2+}$ release from inositol 1,4,5-triphosphate $\left(\mathrm{IP}_{3}\right)$ ryanodine-sensitive stores. J Biol Chem 29: 25870-25876.

Lujan HD, Marotta A, Mowatt MR, Sciaky N, LIPPINCOTT-SCHWARTZ J AND NASH TE. 1995a. Developmental induction of Golgi structure and function in the primitive eukaryote Giardia lamblia. J Biol Chem 270: 4612-4618. 
LuJan HD, Mowatt MR, CONRAD JT, Bowers B AND NASH TE. 1995b. Identification of a novel Giardia lamblia cyst wall protein with leucine-rich repeats. Implications for secretory granule formation and protein assembly into the cyst wall. J Biol Chem 270: 29307-29313.

Lycke E, Norrby R And Remington J. 1968. Penetration-enhancing factor extracted from Toxoplasma gondii, which increases its virulence for mice. J Bacteriol 96: 785-788.

MANNING P, ERLANDSEN SL AND JARROL EL. 1992. Carbohydrate and aminoacid analyses of Giardia muris cysts. J Protozool 39: 290-296.

Marti M ANd Hehl AB. 2003. Encystation-specific vesicles in Giardia: a primordial Golgi or just another secretory compartment? Trends Parasitol 19: 440-446.

MARti M, Li Y, Schraner EM, Wild P, Kohler P AND HEHL AB. 2003. The secretory apparatus of an ancient eukaryote: protein sorting to separate export pathways occurs before formation of transient Golgilike compartments. Mol Biol Cell 14: 1433-1447.

Marti M, Baum J, Rug M, Tilley L ANd Cowman AF. 2005. Signal-mediated export of proteins from the malaria parasite to the host erythrocyte. J Cell Biol 171: 587-592.

Matthiesen SH, Shenoy SM, Kim K, Singer RH AND SATIR BH. 2001a. A parafusin-related Toxoplasma protein in $\mathrm{Ca}^{2+}$-regulated secretory organelles. Eur J Cell Biol 80: 775-783.

Matthiesen SH, Shenoy SM, Kim K, Singer RH AND SATIR BH. 2001b. Role of the parafusin orthologue, PRP1, in microneme exocytosis and cell invasion in Toxoplasma gondii. Cell Microbiol 5: 613-624.

Mazzuco A, Benchimol M And de Souza W. 1997. Endoplasmic reticulum and Golgi-like elements in Entamoeba. Micron 28: 241-247.

MCCAFFERY JM, FAUbert GM AND GILlin FD. 1994. Giardia lamblia: traffic of a trophozoite variant surface protein and a major cyst wall epitope during growth, encystations, and antigenic switching. Exp Parasitol 79: 236-249.

Meissner M, Reiss N, Viebig N, CARruthers VB, Trousel C, Tomavo S, Ajioka JW and
SODATI D. 2002. A family of transmembrane microneme proteins of Toxoplasma gondii contain EGF-like domains and function as escorters. J Cell Sci 115: 563-574.

Mercier C, Lecordier L, Darcy F, Deslée D, Murray A, Tourvieille B, Maess P, Capron A And Cesbron-Delauw MF. 1993. Molecular characterization of a dense granule antigen (GRA2), associated with the network of the parasitophorous vacuole in Toxoplasma gondii. Mol Biochem Parasitol 58: 71-82.

Mercier C, Cesbron-Delauw MF and Sibley LD. 1998a. The amphiphatic and alpha helices of the Toxoplasma protein GRA2 mediate postsecretory membrane association. J Cell Sci 111: 2171-2180.

Mercier C, Howe DK, Mordue D, Lingnau M AND SIBLEY LD. 1998b. Targeted disruption of the GRA2 locus in Toxoplasma gondii decreases the virulence in mice. Infect Immun 66: 4176-4182.

Metsis A, Pettsersen E And Petersen E. 1995. Toxoplasma gondii: characterization of a monoclonal antibody recognizing antigens of 36 and 38 $\mathrm{kDa}$ with acid phosphatase activity located in dense granules and rhoptries. Exp Parasitol 81: 472-479.

Moreno SNJ AND ZHONG L. 1996. Acidocalcisomes in Toxoplasma gondii tachyzoites. Biochem J 813: 655-659.

Morris MT, COPPIN A, TOMAVO S AND CARrUTHERS VB. 2002. Functional analysis of Toxoplasma gondii protease inhibitor 1. J Biol Chem 277: 45259-45266.

MOWATT MR, LuJAN HD, COTTON DB, BOWERS B, YeE J, NASh TE AND STIBbs HH. 1995. Developmentally regulated expression of Giardia lamblia cyst wall protein gene. Mol Microbiol 15: 955-963.

Neudeck A, Stachelhaus S, Nischik N, StriePEN B, Reichmann G AND Fischer HG. 2002. Expression variance, biochemical and immunological properties of Toxplasma gondii dense granule protein GRA 7. Microbes Infect 4: 581-590.

NGô HM, Hoppe HC AND JoINer K. 2000. Differential sorting and post-secretory targeting of proteins in parasitic invasion. Trends Cell Biol 10: 67-72.

NGÔ HM, YAN M AND JOINER K. 2004. Are rhop- 
tries in Apicomplexan parasites secretory granules or secretory lysosomal granules? Mol Microbiol 52: 1531-1541.

OsSORIO PN, SCHWARTZMAN JD AND BOOTHROYD JC. 1992. Toxoplasma gondii rhoptry protein associated with host cell penetration has an unusual charge asymmetry. Mol Biochem Parasitol 50: 1-16.

OsSorio PN, DUbremetz JF AND JoINER KA. 1994. A soluble secretory protein of the intracellular parasite Toxoplasma gondii associated with the parasitophorous vacuole membrane through hydrophobic interactions. J Biol Chem 269: 15350-15357.

Periz J, Gill AC, KNOTt V, HANDFord PA AND TOMLEY FM. 2005. Calcium binding activity of the epidermal growth factor-like domains of the apicomplexan microneme protein EtMIC4. Mol Biochem Parasitol 143: 192-199.

Pezzela N, Bouchot A, Bonhomme A, Pingret L, Klein C, Burlet H, Balossier G, BonHOMME P AND PINON JM. 1997. Involvement of calcium and calmodulin in Toxoplasma gondii tachyzoite invasion. Eur J Cell Biol 74: 92-101.

PRZYBORSKI JM AND LANZER M. 2005. Protein transport and trafficking in Plasmodium falciparuminfected erythrocytes. Parasitology 130: 373-388.

PrZYBorski JM, WiCKERT H, KROHNE G AND LANZER M. 2003. Maurer's cleft-a novel secretory organelle? Mol Biochem Parasitol 132: 17-26.

Pszenny V, Ledesma Be, Matrajt M, Duschak VG, Bontempi EJ, Dubremetz JF AND ANGEL SO. 2002. Subcellular localization and post-secretory targeting of $\mathrm{TgP} 1$, a serine proteinase inhibitor from Toxoplasma gondii. Mol Biochem Parasitol 121: 283-286.

Rabenau Ke, Sohrabi A, Tripathy A, Reitter C, AJIOKA JW, TOMLEY FM AND CARRUTHERS VB. 2001. TgM2AP participates in Toxoplasma gondii invasion of host cells and is tightly associated with the adhesive protein TgMIC2. Mol Microbiol 41: 537-547.

Reiss M, Viebig N, Brecht S, Formaux MN, Soete M, Di Cristina M, Dubremetz J AND SoldATI D. 2001. Identification and characterization of an escorter for two secretory adhesions in Toxoplasma gondii. J Cell Biol 152: 563-578.
SAFFer LD, Mercereau-PuiJalon O, Dubremetz JF AND SCHWARTZMAN JD. 1992. Localization of Toxoplasma gondii rhoptry protein by immunoelectron microscopy during and after cell penetration. J Protozool 39: 526-530.

SAM-YELLOWE TY. 1999. Rhoptry organelles of the Apicomplexa: their role in host cell invasion and intracellular survival. Parasitol Today 12: 308-316.

SAM-Yellowe TY, Shio H AND PER KINS ME. 1988. Secretion of Plasmodium falciparum rhoptry protein into the plasma membrane of the host erythrocytes. J Cell Biol 106: 1507-1513.

SANCHEZ-LOPEZ R, GAMA-CASTRO S, RAMOS MA, Merino E, Lizardi PM AND Alagon A. 1998. Cloning and expression of the Entamoeba histolytica ERD2 gene. Mol Biochem Parasitol 92: 355-359.

SAOUROS S ET AL. 2005. A novel galectin-like domain from Toxoplasma gondii micronemal protein 1 assists the folding, assembley, and transport of a cell adhesion complex. J Biol Chem 280: 38583-38591.

SCHWAB JC, BECJERS CJM AND JOINER KA. 1994. The parasitophorous vacuole membrane surrounding intracellular Toxoplasma gondii functions as a molecular sieve. Proc Natl Acad Sci 91: 509-513.

SCHWARTZMAN JD. 1986. Inhibition of a penetrationenhancing factor of Toxoplasma gondii by monoclonal antibodies specific for rhoptries. Infect Immun 51: 760-764.

Schwarz JA, Fouts AE, Cummings CA, FerguSON DJP AND BoOTHROYD JC. 2005. A novel rhoptry protein in Toxoplasma gondii bradyzoites and merozoites. Mol Biochem Parasitol 144: 159166.

ShaW MK, Roos DS And TILney LG. 1998. Acidic compartments and rhoptry formation in Toxoplasma gondii. Parasitology 117: 308-316.

Sibley LD, NeISMan JR, ASAI T AND TAKeUChI T. 1994. Toxoplasma gondii: Secretion of a potent nucleoside triphosphate hydrolase into the parasitophorous vacuole. Exp Parasitol 79: 301-311.

Sibley LD, Neisman JR, Parmley SF and CesBRON-DELAUW MF. 1995. Regulated secretion of multi-lamellar vesicles leads to formation of a tubulovesicular network in host-cell vacuoles occupied by Toxoplasma gondii. J Cell Sci 108: 1669-1677. 
Silverman JA, QI H, Riehl A, Beckers C, NAKAAR V AND JOINER KA. 1998. Induced activation of the Toxoplasma gondii nucleoside triphosphatase hydrolase leads to depletion of host cell ATP levels and rapid exit of intracellular parasites from infected cells. J Biol Chem 273: 12352-12359.

SIM BKL. 1995. EBA-175: An erythrocyte-binding ligand of Plasmodium falciparum. Parasitol Today 11: 213-217.

SinAI AP AND JOINER KA. 2001. The Toxoplasma gondii protein ROP2 mediates host organelle association with the parasitophorous vacuole. J Cell Biol 154: $95-108$.

Sinai AP, Webster P And Joiner KA. 1997. Association of the host cell endoplasmic reticulum and mitochondria with the Toxoplasma gondii parasitophorous vacuole membrane: a high affinity interaction. J Cell Sci 110: 2117-2128.

Soldati D, Dubremetz JF AND Lebrun M. 2001. Microneme proteins: structural and functional requirements to promote adhesion and invasion by the apicomplexan parasite Toxoplasma gondii. Int J Parasitol 31: 1293-1302.

Souto-PAdrón T, CAmpetella oE, Cazzulo JJ AND DE SouzA W. 1990. Cysteine proteinase in Trypanosoma cruzi: Immunocytochemical localization and involvement in parasite-host cell invasion. $\mathrm{J}$ Cell Sci 96: 485-490.

Stierhof Y-D, Ilg T, Russel DG, Hohenberg H AND OVERATH P. 1994. Characterization of polymer release from the flagellar pocket of Leishmania mexicana promastigotes. J Cell Biol 125: 321-331.

STOMMEL EW, ELY KH, SCHWARTZMAN JD AND KASPER LH. 1997. Toxoplasma gondii: dithiolinduced $\mathrm{Ca}^{2+}$ flux causes egress of parasites from the parasitophorous vacuole. Exp Parasitol 87: 8897.

Striepen B, Soldati D, Garcia-Reguet N, Dubremetz JF AND Roos DS. 2001. Targeting of soluble proteins to the rhoptries and micronemes in Toxoplasma gondii. Mol Biochem Parasitol 92: 325-338.
Sultan AA, Thathy V, Frevert U, Robson KJH, Crisanti A, Nussenzweig V, Nussenzweig RS AND MENARD R. 1997. TRAP is necessary for gliding motility and infectivity of plasmodium sporozoites. Cell 90: 511-522.

TobIE JE AND COATNEY GR. 1961. Fluorescent antibody staining of human malarial parasites. Exp Parasitol 11: 128-132.

Touz MC, Nores MJ, SLAVIn I, CARMONA C, CONRad JT, Mowatt MR, Nash TE, Coronel CE AND LÚJAN HD. 2002. The activity of a developmentally regulated cysteine proteinase is required for cyst wall formation in the primitive eukaryote Giardia lamblia. J Biol Chem 277: 8474-8481.

Trager W, Rudzinska MA AND BRAdBuRy PC. 1966. The fine structure of Plasmodium falciparum and its host erythrocyte in natural malarial infections in man. Bull Wld Hlth Org 35: 883-885.

TRIGGS VP AND BANGS JD. 2003. Glycosylphosphatidylinosito-dependent protein trafficking in bloodstream stage Trypanosoma brucei. Euk Cell 2: 76 83

VIEIRA MCF AND Moreno SNJ. 2000. Mobilization of intracellular calcium upon attachment of Toxoplasma gondii tachyzoites to human fibroblasts is required for invasion. Mol Biochem Parasitol 106: $157-162$.

WAN KL, CARruthers VB, Sibley LD AND AJIOKA JW. 1997. Molecular characterization of an expressed sequence tag locus of Toxoplasma gondii encoding the micronemal protein MIC2. Mol Biochem Parasitol 84: 203-214.

Wickert H, Wissing F, ANDrews KT, STich A, KroHne G AND LANZER M. 2003. Evidence for trafficking of PfEMP1 to the surface of P. falciparuminfected erythrocytes via a complex membrane network. Eur J Cell Biol 82: 271-284.

ZhaO H AND SATIR BH. 1998. Parafusin is a membrane and vesicle associated protein that cycles at exocytosis. Eur J Cell Biol 75: 46-53. 